\title{
Polydiacetylene Vesicles Acting as Colorimetric Sensor for the Detection of Plantaricin LD1 Purified From Lactobacillus Plantarum LD1
}

Manoj Kumar Yadav

Maharshi Dayanand University Rohtak

Santosh Kumar Tiwari ( $\nabla$ santoshgenetics@mdurohtak.ac.in )

M.D. University https://orcid.org/0000-0003-1477-1845

\section{Research Article}

Keywords: Plantaricin LD1, Nisin, Colorimetric response, FTIR, SEM, PDA Vesicles

Posted Date: March 18th, 2021

DOI: https://doi.org/10.21203/rs.3.rs-298007/v1

License: (c) (i) This work is licensed under a Creative Commons Attribution 4.0 International License.

Read Full License 


\section{Abstract}

The interaction of antimicrobial peptides with membrane lipids plays a major role in numerous physiological processes. Bacteriocins are antimicrobial peptides known to kill target cells by pore formation and membrane disruption. In this study, polydiacetylene (PDA) vesicles were applied as artificial membrane for detection of plantaricin LD1 purified from Lactobacillus plantarum LD1. Plantaricin LD1 $(200 \mu \mathrm{g} / \mathrm{ml})$ was able to change the color of PDA vesicles from blue to red with colorimetric response CR $\% 30.26 \pm 0.59$. Nisin $(200 \mu \mathrm{g} / \mathrm{ml})$, used as control, also changed the color of the vesicles with $\mathrm{CR} \% 50.56 \pm 0.98$ validating the membrane-acting nature of these bacteriocins. The PDA vesicles treated with nisin and plantaricin LD1 showed increased infrared absorbance at 1411.46 $\mathrm{cm}^{-1}$ and $1000-1150 \mathrm{~cm}^{-1}$ indicated the interaction of bacteriocins with phospholipids and fatty acids, respectively. Further, microscopic examination also suggested the disruption of bacteriocin-treated vesicles indicating the interaction of bacteriocins. These findings suggest that the PDA vesicles may be used as bio-mimetic sensor for the detection of bacteriocins produced by several probiotics in food and therapeutic applications.

\section{Introduction}

The cell membrane is one of the most fundamental constituents in biological systems creating the physical boundaries and also plays important roles in transducing signals, sensing environmental conditions, recognizing and transporting ions/molecules [1]. The major components of the cell membranes are amphiphilic lipids, cholesterols and membrane proteins. Artificial membranes are traditionally reconstructed either by lipid solution or by folding two monolayers [2]. Membranes, synthesized using traditional methods, are not suitable for bio-sensor applications due to their fragility and low resistance. Thus, bio-mimetic membranes with modified lipids have become useful tools in biosensing applications. In recent years, a number of techniques have been developed to create the biomimetic membranes with the help of synthetic lipids and polymers. They have widened the field of applicability of bio-mimetic membrane systems for the detection of new biological membrane-acting compounds [1].

The polydiacetylene (PDA) vesicles consist of phospholipid such as dimyristoylphosphatidylcholine (DMPC) and lipid, 10, 12-tricosadiynoic acid (TRCDA) in aqueous solutions exhibiting blue color due to the presence of conjugated poly (ene-yne) backbone [3, 4]. PDA constitutes a class of conjugated ene-yne polymer assembly produced upon ultraviolet irradiation $(254 \mathrm{~nm})$ of ordered diacetylene monomers which exhibit unique optical properties, first prepared by Wegner [5]. However, its potential use in sensing application was first explored by Charych et al. [6]. The PDA vesicles have received tremendous attention in the field of chemical and biological sciences as a colorimetric sensor due to their capacity to change the color when exposed to various external stimuli such as light, heat, mechanical stress, solvents and binding of specific chemical or biological agents [7-9]. The blue phase of the vesicles shows maximum absorption at $640 \mathrm{~nm}$ and red phase, at $550 \mathrm{~nm}$ when exposed to external stimuli, which can be directly observed by the naked eyes [10-12]. The color transition of the vesicles is associated with a 
conformational change in its structure [13]. The phospholipid forms a micro domain within the PDA matrix that resemble biological plasma membrane and the color change of PDA vesicles from blue to red occurs following interactions between membrane-acting compounds and the head group of phospholipids bilayer micro-domains [14]. The infrared (IR) spectroscopy such as Fourier-transform infrared (FTIR) analysis has been frequently used for investigating the structure or bond change of PDA vesicles due to blue-red transitions induced by external stimuli [15]. PDA vesicles have drawn attentions in recent years for the applications in biosensors such as the detection of membrane-acting peptides, viruses, ions and bacteria [16].

Several antimicrobial peptides such as meganin II, melittin, alamethicin and nisin [17, 18,] are known for color transition of PDA vesicles and induce colorimetric response (CR\%) [16]. These peptides are generally believed to kill bacteria through peptide-lipid interaction leading to membrane permeabilization and extensive pore-formation [19]. Membrane-acting peptides are usually small, cationic and watersoluble with variety of biologically important effects arising from their interactions with cell membranes [20]. These peptides bind to a membrane surface below a threshold peptide to lipid ratio and form pores, resulting in membrane depolarization and leakage of cell components leading to cell death [21]. Bacteriocins are small cationic peptides produced by different bacterial species in their ecological niches as part of defence mechanism and competitive advantages $[22,23]$.

Lactobacillus plantarum LD1 was previously isolated and identified for probiotic potential and bacteriocin production [24]. In this study, plantaricin LD1 has been purified from cell-free supernatant of L. plantarum LD1 using ultrafiltration and activity-guided chromatography. The PDA vesicles were synthesized and used as artificial membrane to evaluate the interaction of plantaricin LD1 using colorimetric response, FTIR analysis and scanning electron microscopy.

\section{Materials And Methods}

\subsection{Bacterial strains, culture media and reagents}

L. plantarum LD1 was grown in MRS (De man, Rogosa and Sharpe) medium (Hi-media, Mumbai, India) for $18 \mathrm{~h}$ at $37^{\circ} \mathrm{C}$ as suggested by Gupta et al. [25]. Micrococcus luteus MTCC106 was grown in Nutrient Broth (NB) medium (Hi-media, Mumbai, India) at $37^{\circ} \mathrm{C}$ for $18 \mathrm{~h}$ with continuous shaking at $200 \mathrm{rpm}$ and used as indicator strain [26]. The diacetylene monomer 10, 12-tricosadiynoic acid (TRCDA) and nisin were purchased from Sigma (St. Louis, USA) and synthetic phospholipid, 1, 2-dimyristoyl-sn-glycero-3phosphocholine (DMPC) was purchased from Avanti Polar Lipids (Alabaster, USA). The chloroform and tris(hydroxymethyl) amino methane (extra pure) were purchased from Sisco Research Laboratory (Mumbai, India).

\subsection{Purification of plantaricin LD1}

Plantaricin LD1 was purified using Tangential Flow Filtration (TFF), cation-exchange and gel-filtration chromatography. The cell-free supernatant (CFS) was collected from $18 \mathrm{~h}$ grown culture of L. plantarum 
LD1 through centrifugation (10,000 rpm for 15 min at $4^{\circ} \mathrm{C}$ ) (Sigma, Osterode am Harz, Germany) and filter-sterilized using $0.2 \mu \mathrm{m}$ membrane (Axiva, New Delhi, India). It was passed through $10 \mathrm{kDa}$ NMWCO hollow fibre cartridge fitted with AKTA Flux-S (GE Healthcare, Uppsala, Sweden) at a feed pressure of 0.44 bar, retentate pressure of $0.27 \mathrm{bar}$, transmembrane pressure of $0.21 \mathrm{bar}$, flux of $14.8 \mathrm{Imh}$ and flow rate of $80 \mathrm{ml} / \mathrm{min}$ as described previously [27]. The retentate was discarded and permeate $(900 \mathrm{ml})$ was further passed through $3 \mathrm{kDa}$ NMWCO hollow fibre cartridge under same conditions. The $3 \mathrm{kDa}$ retentate (100 $\mathrm{ml}$ ) was washed with sodium acetate buffer $(10 \mathrm{mM}, \mathrm{pH}$ 4.5), lyophilized (Macflow, New Delhi, India) and dissolved in $10 \mathrm{ml}$ of same buffer. The solution was filter-sterilized using $0.2 \mu \mathrm{m}$ membrane filter (Axiva, New Delhi, India) and mentioned as fraction I. The protein concentration was determined using Bradford method as described by Yuan et al. [28]. The antimicrobial activity was determined using agar well diffusion assay (AWDA) as describe by Yadav et al. [3]. Briefly, $5 \mathrm{ml}$ soft nutrient agar (0.8\%) medium already seeded with indicator strain, M. luteus MTCC106 $\left(\sim 10^{-6} \mathrm{CFU} / \mathrm{ml}\right)$ was overlaid on solid agar (1.5 $\%)$ medium and cut the wells $(6 \mathrm{~mm})$ on assay plate. The $3 \mathrm{kDa}$ retentate $(100 \mu \mathrm{l})$ was loaded in the wells and the assay plate was incubated at $37^{\circ} \mathrm{C}$ for $18 \mathrm{~h}$. The zone of growth inhibition was observed around the wells and measured in millimetre $(\mathrm{mm})$ after incubation.

The cation-exchange chromatography was performed as described previously [26]. Briefly, the column, HiPrep SP FF 16/10 (1.6 X $10 \mathrm{~cm}, 20 \mathrm{ml})$ fitted with AKTA prime plus system (GE Healthcare, Uppsala, Sweden) was equilibrated with sodium acetate buffer $(10 \mathrm{mM}, \mathrm{pH} 4.5)$ at flow rate $1 \mathrm{ml} / \mathrm{min}$. The fraction I $(20 \mathrm{ml})$ was loaded on the column at flow rate $0.5 \mathrm{ml} / \mathrm{min}$ and column was washed with same buffer ( $3 x$ bed volume) to remove unbound proteins. The elution was performed at flow rate $1 \mathrm{ml} / \mathrm{min}$ with a linear gradient of $0-1 \mathrm{M} \mathrm{NaCl}$ in same buffer and fractions $(1.0 \mathrm{ml})$ were collected throughout the run. The protein elution profile was monitored at $214 \mathrm{~nm}$. Tricine SDS-PAGE was performed with narrow range protein marker (3.5 to $43 \mathrm{kDa}$ ) (GeNei, Karnataka, India) to analyse protein bands as described by Kaur and Tiwari [26]. The antimicrobial activity was determined using AWDA against M. luteus MTCC106 as described above and fractions showing antimicrobial activity were pooled and concentrated using lyophilization (Fraction II).

The gel-filtration chromatography of fraction II was performed using sephadex G-50 column $(1.6 \times 50 \mathrm{~cm}$, $100 \mathrm{ml}$ ) (GE Healthcare, Uppsala, Sweden) fitted with AKTA prime plus system and equilibrated with filtersterilized double distilled water $\left(\mathrm{ddH}_{2} \mathrm{O}\right)$. The Fraction II $(1 \mathrm{ml})$ was loaded on to column and elution was performed with $\mathrm{ddH}_{2} \mathrm{O}$ at flow rate $0.2 \mathrm{ml} / \mathrm{min}$. The elution profile was monitored at $214 \mathrm{~nm}$, conductivity was recorded in terms of millisiemens per centimeter $(\mathrm{mS} / \mathrm{cm})$ and $1 \mathrm{ml}$ fractions were collected. The protein concentration in the eluted fractions was determined using Bradford method [28], purity was tested using tricine SDS-PAGE [26] and antimicrobial activity was determined using AWDA [3]. The fraction showing single protein band with antimicrobial activity was considered as purified bacteriocin and used in further experiments.

\subsection{Preparation of PDA vesicles}


The PDA vesicles were freshly prepared with 10, 12-tricosadiynoic acid (TRCDA) (Sigma, St. Louis, USA) and 1, 2-dimyristoyl-sn-glycero-3-phosphocholine (DMPC) (Avanti polar lipids, Alabaster, USA) as described previously [3]. Briefly, the stock solutions (10 mM) of TRCDA and DMPC were mixed in 2:3 ratio in $10 \mathrm{ml}$ chloroform. Chloroform was evaporated at $50^{\circ} \mathrm{C}$. After evaporation, solution was maintained in double distilled water $\left(\mathrm{ddH}_{2} \mathrm{O}\right)$ at $1 \mathrm{mM}$ total lipid concentration. The sample was heated at $80-90^{\circ} \mathrm{C}$ during probe sonication with $50 \%$ amplitude for $10 \mathrm{~min}$ and stored at $4{ }^{\circ} \mathrm{C}$ after sonication. Next day sample was brought at room temperature and vesicles were polymerised using UV-light at $254 \mathrm{~nm}$ showing blue color.

\subsection{Treatment of vesicles with bacteriocins}

An aliquot of $100 \mu \mathrm{l}(1 \mathrm{mM})$ PDA vesicles was added in the wells of microtiter plate (Tarson, Kolkata, India) and treated with different concentrations of nisin (5, 20, 40, 80, 100, 150 and $200 \mu \mathrm{g} / \mathrm{ml}$ ) (Sigma Aldrich, St. Louis, USA) in the presence of $10 \mu$ Tris-HCl buffer $(2 \mathrm{mM}, \mathrm{pH} 8.0)$ as suggested by Kumariya et al. [29]. The PDA vesicles were also treated with different concentrations of purified plantaricin LD1 (5, $20,40,80,100,150$ and $200 \mu \mathrm{g} / \mathrm{ml}$ ) in the same conditions. The color change of the vesicles was observed at $540 \mathrm{~nm}$ (for red color) and $640 \mathrm{~nm}$ (for blue color) using micro plate reader (Molecular Devices, Sunnyvale, USA) [3]. The percentage of color change from blue to red was determined in the terms of colorimetric response (CR \%) $[30,31]$ after 5 min incubation at room temperature as described below:

$\mathrm{CR} \%=\left(\mathrm{PB}_{0}-\mathrm{PB}_{\mathrm{f}}\right) / \mathrm{PB}_{0} \times 100 \%$

Where PB $=A_{\text {blue }} /\left(A_{\text {blue }}+A_{\text {red }}\right) \times 100 \%$ and $A$ is the absorbance at either the "blue" component in the UVvisible spectrum $(640 \mathrm{~nm})$ or the "red" component $(540 \mathrm{~nm}) . \mathrm{PB}_{0}$ is the initial percent blue without bacteriocin, and $\mathrm{PB}_{f}$ is the final percent blue obtained after bacteriocin reaction $[11,29,32]$.

\subsection{Fourier transform infrared (FTIR) spectroscopy}

The effect of plantaricin LD1 on PDA vesicles was studied using FTIR spectroscopy as described by Ortuso et al. [16]. Briefly, PDA vesicles were treated with nisin $(100 \mu \mathrm{g} / \mathrm{ml})$ and plantaricin LD1 (100 $\mu \mathrm{g} / \mathrm{ml}$ ), and incubated at room temperature for $5 \mathrm{~min}$. The untreated PDA vesicles were used as negative control and nisin-treated PDA vesicles as positive control. The absorbance spectra of treated and untreated vesicles were acquired using an FTIR spectrophotometer (Bruker, Bremen, Germany) on diamond attenuated total reflectance (ATR) accessory. Opus software was used for spectra acquisition as suggested by Boumehira et al. [33]. An aliquot of $10 \mu \mathrm{l}$ of the vesicles $(0.5 \mathrm{mM})$ were placed in direct contact with the internal reflecting diamond crystal. Once in contact with the diamond crystal, multiple scans were obtained to reduce error. Each spectrum was baseline corrected and spectral range was set from 800 to $1800 \mathrm{~cm}^{-1}$ at a resolution of $8 \mathrm{~cm}^{-1}$. The spectra of treated and untreated vesicles were analysed in the range of $1000-1150$ and $1411.46 \mathrm{~cm}^{-1}$ corresponding to fatty acids and phospholipids, respectively as suggested by Zoumpopoulou et al. [34].

\subsection{Microscopic examination of PDA vesicles}


The change in morphology of the vesicles was observed under light microscope (Labomed vision 2000, Fremont, USA) and scanning electron microscope (EVO 18, Zeiss, Jena, Germany). Light microscopy was performed with an aliquot of $20 \mu \mathrm{l}$ each of treated and untreated PDA vesicles on glass slide and covered with cover slip. The glass slide was mounted with emersion oil and morphological changes were observed directly at $100 \times$ magnification. For further confirmation of effects of bacteriocins on PDA vesicles, scanning electron microscope (SEM) was used as suggested by Ritenberg et al. [35]. For this, vesicles were fixed with primary fixative $(2.5 \%$ glutaraldehyde and $2 \%$ paraformaldehyde in $0.1 \mathrm{M}$ sodium phosphate buffer, $\mathrm{pH} 7.4$ for $4 \mathrm{~h}$ at $4^{\circ} \mathrm{C}$ ) and the fixative was removed using centrifugation $\left(10,000 \mathrm{rpm}\right.$ for $10 \mathrm{~min}$ at $\left.4^{\circ} \mathrm{C}\right)$. The secondary fixative ( $1 \%$ Osmium tetroxide solution) was added for 1 $\mathrm{h}$ at $4^{\circ} \mathrm{C}$ and removed. The dehydrating agent (ethanol) was added to remove water from the sample. After dehydration, the sample was dried using hexamethyldisilazane (HMDS) and mounted on a SEM mount or stub. The sample was coated with mixture of gold and palladium (Au/Pd) (6:4) and sputter was coated with argon gas. The effects of bacteriocins on morphology of the vesicles were observed under SEM with $10.25 \mathrm{Kx}$ magnification. The SEM was performed at Sophisticated Analytical Instrumentation Facility, All India Institute of Medical Science, New Delhi, India.

\subsection{Statistical analysis}

Experiments were performed in triplicate, mean values were plotted along with standard deviation (mean $\pm S D$ ), and $p<0.05$ was considered as statistically significant. Where necessary, three independent experiments were performed to monitor the reproducibility of results.

\section{Results}

\subsection{Plantaricin LD1 was purified to homogeneity}

The $3 \mathrm{kDa}$ retentate of ultra-filtered plantaricin LD1 showed $20 \pm 0.12 \mathrm{~mm}$ zone of growth inhibition against indicator strain, Micrococcus luteus MTCC106. The protein concentration was found to be 0.95 $\mathrm{mg} / \mathrm{ml}$. The CEC of this sample showed two peaks (Fig. 1A) and the pooled fractions of first peak showed smear protein band [Fig. 1B (lane II)] with $13 \pm 0.25 \mathrm{~mm}$ zone of growth inhibition (Fig. 1C) whereas second peak [Fig. 1B (lane I)] did not show antimicrobial activity (Fig. 1C) and discarded. The first peak when run on gel-filtration chromatography (GFC), showed two peaks (Fig. 1D). The first peak of GFC did not show activity and discarded whereas second peak showed $16 \pm 0.15 \mathrm{~mm}$ zone of growth inhibition (Fig. 1F). The SDS-PAGE analysis of first peak further showed smear [Fig. 1E (lane I)] and second peak showed single $6.5 \mathrm{kDa}$ protein band indicating the purity of the bacteriocin sample [Fig. $1 \mathrm{E}$ (lane II)].

\subsection{PDA vesicles interact with bacteriocins}

The untreated PDA vesicles showed blue color at $640 \mathrm{~nm}$ and vesicles treated with 5 and $20 \mu \mathrm{g} / \mathrm{ml}$ plantaricin LD1 did not change the color whereas, treated with $40 \mu \mathrm{g} / \mathrm{ml}$ changed the color blue to light greenish and showed lowest CR \% 4.17 \pm 0.90 . The vesicles treated with $200 \mu \mathrm{g} / \mathrm{ml}$ plantaricin LD1 
changed the color blue to dark brown and showed the highest CR $\% 30.26 \pm 0.59$. The blue color of PDA vesicles was changed to greenish with $\mathrm{CR} \% 7.85 \pm 0.68$ after treatment with $80 \mu \mathrm{g} / \mathrm{ml}$ plantaricin LD1. The PDA vesicles treated with $100 \mu \mathrm{g} / \mathrm{ml}$ plantaricin LD1 were changed to light brown color and showed the $\mathrm{CR} \% 16.45 \pm 0.85$, whereas vesicles showed brown color and CR $\% 25.73 \pm 0.79$ after treatment with $150 \mu \mathrm{g} / \mathrm{ml}$ plantaricin LD1 as shown in Fig. 2(A). Similarly, vesicles treated with nisin $(5 \mu \mathrm{g} / \mathrm{ml})$ did not change the color and remained blue color, whereas light purple color with $\mathrm{CR} \% 8.23 \pm 0.85$ was observed after treatment with $20 \mu \mathrm{g} / \mathrm{ml}$ nisin. The color of PDA vesicles was changed blue to purple with CR \% $20.26 \pm 0.98$ and $28.58 \pm 0.68$ after treatment with 40 and $80 \mu \mathrm{g} / \mathrm{ml}$ nisin respectively, and showed light pink color with CR \% $37.56 \pm 0.85$ after treatment with $100 \mu \mathrm{g} / \mathrm{ml}$ nisin. The vesicles showed pink color with CR \% $48.54 \pm 0.78$ and $50.56 \pm 0.98$ after treatment with 150 and $200 \mu \mathrm{g} / \mathrm{ml}$ nisin as shown in Fig. 2(B). There was increasing trend of $\mathrm{CR} \%$ and pink/red color intensity recorded with increasing concentration of bacteriocins suggesting the interaction.

\subsection{Fourier transform infrared (FTIR) spectroscopy}

The vesicles treated with nisin $(100 \mu \mathrm{g} / \mathrm{ml})$ and plantaricin LD1 $(100 \mu \mathrm{g} / \mathrm{ml})$ showed significant increase in the absorbance at $1411.46 \mathrm{~cm}^{-1}$ corresponding to phospholipids and also changed the color from blue to pink/red respectively, whereas the untreated vesicles did not show such changes in the absorbance and remained blue in color as shown in Fig. 3. The minor increase in the absorbance was also observed in the bacteriocin-treated vesicles in the range of $1000-1150 \mathrm{~cm}^{-1}$ could be due to binding of bacteriocins with fatty acid (Fig. 3). Thus, the changes in the spectra near phospholipid/fatty acid region suggest the interaction of bacteriocins with vesicles.

\subsection{Microscopic examination reveals broken vesicles after the treatment}

The untreated PDA vesicles were found to be blue and round shaped under light microscope as shown in Fig. 4(A) whereas vesicles treated with plantaricin LD1 and nisin were found to be pink color, swollen with broken outer boundary (Fig. 4B-C). Under SEM, untreated vesicles were normal in shape (Fig. 4D) but plantaricin LD1-treated vesicles were found disrupted, larger in size and clumped (Fig. 4E). The nisintreated vesicles were also found clumped with broken outer surfaces and smaller in size as shown in Fig. 4(F). The changes in the morphology of treated vesicles further suggested the interaction of bacteriocins with vesicles.

\section{Discussion}

The antimicrobial peptides (AMPs) are used as alternatives to clinical antibiotics. Still many AMPs show toxic effect on mammalian cells, whereas bacteriocins of probiotic lactic acid bacteria (LAB) lack such drawback [36]. The antimicrobial activity of bacteriocins against sensitive strains is probably linked to the membrane interaction with the target cells. The cells have negatively charged phospholipids 
asymmetrically distributed in the outer membrane leaflet [37]. It is generally assumed that the cationic peptides interact with negatively charged head group of bacterial phospholipids permeabilizing the cell membranes [38]. There are several reports available about interaction of bacteriocins with plasma membrane of target bacteria forming pores and membrane permeabilization resulting in the dissipation of membrane potential and efflux of several ions and macromolecules $[39,40]$. However, reports on bacteriocins interacting with synthetic vesicles is limited which needs to be explored for various biotechnological applications of these peptides.

PDA vesicle-based colorimetric assay is simple and easy suggesting potential applications in diverse fields [40]. PDA vesicles are widely explored as biosensors/biomimetic nature because these polymers can be synthesized in situ only with the assistance of light in the desired environment and addition of phospholipids into the PDA bilayer matrix to increase the fluidity of the artificial cell membrane-like assembly [41]. In our previous study, PDA vesicles were prepared, optimized and used for the screening of bacteriocins and halocins from LAB and haloarchaea, respectively [18]. The vesicle-based colorimetric assay was also compared with other indicator-dependent conventional methods for the screening of bacteriocin-producing strains of LAB [3]. Previously, we have demonstrated the production of plantaricin LD1 by a putative probiotic strain of $L$. plantarum LD1 [24, 42]. In this study, biomimetic nature of PDA vesicles was studied with plantaricin LD1 along with a known bacteriocin, nisin.

The untreated PDA vesicles were found blue whereas nisin and plantaricin LD1 treated vesicles were pink/red. The color change of treated-vesicles was due to interaction of bacteriocins with PDA vesicles. The negatively charged phospholipids within lipid bilayers play important roles in promoting binding of bacteriocins and their insertion into the membrane [37]. The change in the color is triggered by the binding of a target molecules with sensing probes such as peptides, DNA aptamers and antibodies conjugated to the pendant side chains of PDA [43]. The cationic nature of nisin and plantaricin LD1 could be responsible for binding with negatively charged phospholipid. Therefore, PDA vesicles used in this study were found to be highly sensitive to plantaricin LD1 and nisin. Similar reports for other membraneactive peptides such as melittin, gramicidin, alamethicin, dermaseptin, cecropin, magainin, defensins, cathelicidins and pediocin are also available suggesting the interaction of these peptides with lipid vesicles [1, 14, 29]. Kumariya et al. [29] determined the role of cell membrane phospholipids during resistance development against cationic antimicrobial peptides (CAMPs) in Enterococcus faecalis and interaction of CAMPs with cell membrane components such as phospholipids and fatty acids using PDA (polydiacetylene)-biomimetic membranes. Further, the vesicles could be able to detect lower concentration of plantaricin LD1 in solution and resulted in an increase in color change and CR\% indicating the sensitivity of the assay. The applications of PDA vesicles based sensors have also been explored in the other areas such as high-throughput screening of membrane acting antimicrobial peptides, pathogenic/food borne bacteria [11] and viruses (Influenza and latest coronavirus SARS-CoV-2) [41]. The authors have demonstrated great potential in providing a simple, low-cost, accurate and fastspeed detecting method alternative for the current methods which are too expensive and time-consuming for analyzing a large number of samples [44]. The PDA vesicles were used as paper strip sensor for the detection of spores of Bacillus thuringiensis HD-73 [43]. The ratio of DMPC: PDA (2:3) allowed rapid drug 
screening of the permeability across lipid membranes that can be read through "color coding" based on the colorimetric properties of polydiacetylene [45].

The zwitterionic phospholipids are main component of biological cell membrane therefore mixing of phospholipid such as dimyristoylphosphatidylcholine (DMPC) with diacetylene monomer 10, 12 tricosadiynoic acid (TRCDA) to make a natural cell membrane. The phosphocholine head group of DMPC and carboxyl head groups of TRCDA are mimics peptide-cell membrane interactions [14]. The infrared (IR) spectroscopy has been frequently used for investigating the structural change during the polymerization and the mechanism of the blue-to-red transition due to its ability to keep track on the bond change [16]. The membrane-acting nature of plantaricin LD1 was further confirmed by analyzing the FTIR spectra. The vesicles treated with plantaricin LD1 showed increased absorbance at the region 1411.46 and $1000-1150 \mathrm{~cm}^{-1}$ which could be due to symmetric stretching of in-plane bending of $\mathrm{C}-\mathrm{O}-\mathrm{H}, \mathrm{CH}_{2}$ group and C-O-P, CO-O-C groups of phospholipid and fatty acid, respectively as suggested by Gomes et al. [46]. The UV irradiation induces cleavage of $\mathrm{C}-0, \mathrm{C}=\mathrm{O}$ and $-\mathrm{PO}^{2}$ - bonds in to the anionic 1, 2-dipalmitoylsn-glycero-3-[phospho-rac-(1-glycerol)] (sodium salt) (DPPG) phospholipid, which is an important component of cell membranes were investigated by Gomes et al. [46]. Ortuso et al. [16] performed a detailed deconvolution analysis of attenuated total reflection (ATR)-Fourier transform infrared (FTIR) peaks of a common diacetylene, 10, 12-tricosadiynoic acid (TRCDA) during the polymerization and the blue-to-red transition. In this study, increase in the absorbance could be due to interaction of nisin and plantaricin LD1 with negatively charged phosphate group situated in the head group of phospholipids of membrane resulting in the breakage of PDA vesicles. In the previous study, FTIR analysis of Micrococcus Iuteus, Listeria monocytogenes and Escherichia coli cells treated with bacteriocin LB44, enterocin LD3, cerein $8 \mathrm{~A}$ and plantaricin LD4 cells demonstrated similar changes in the absorbance $[26,39]$ suggesting similarity between live cells and artificial membranes against bacteriocins.

The untreated PDA vesicles showed uniform boundary and presented continuous-smooth outer membrane, whereas plantaricin LD1-treated vesicles showed morphological changes such as enlarged size, disruption in outer membrane and pink color. The same has also been confirmed by nisin which is known to interact with the cell membrane of target bacteria [47]. The bilayer-structured PDA vesicles in physiological environments can be easily obtained from the assembly of amphiphilic diacetylene monomers with phospholipids incorporated, which resemble the cellular membrane structure, making them ideal for bio-sensing purposes and for studying protein-membrane interactions [41]. In this membrane model the visible quantifiable color changes were monitored in after peptide membrane interactions [48]. These findings suggested that PDA vesicles mimicking as membrane of lives cells after treatment with bacteriocins and may be applied in various applications for the detection of bacteriocins and other related biomolecules.

\section{Conclusion}

The plantaricin LD1 was purified from CFS of food isolate, L. plantarum LD1. The purified bacteriocin was able to change the color of PDA vesicles from blue to red after the interaction. Similar observation 
was recorded with nisin also used as control. The interaction of bacteriocins with phospholipids was further confirmed using FTIR analysis. The shape of the PDA vesicles was changed after interaction with nisin and plantaricin LD1 as observed under light and scanning electron microscopy. Thus, findings suggested that PDA vesicles may be used as indicator membrane for the detection of bacteriocins and high-throughput screening of related drugs.

\section{Declarations}

\section{Acknowledgements}

MKY acknowledges fellowships by the Department of Biotechnology (DBT), Indian Council of Medical Research (ICMR) and University Research Scholarship (URS), Department of Genetics, Maharshi Dayanand University, Rohtak.

Ethics approval: Not applicable.

Consent to participate: Not applicable.

Consent for publication: Not applicable.

Authors' contributions: All authors contributed to the study conception and design. Material preparation, data collection and analysis were performed by Manoj Kumar Yadav. The first draft of the manuscript was written by Manoj Kumar Yadav and Dr. Santosh Kumar Tiwari commented on previous versions of the manuscript. All authors read and approved the final manuscript. Dr. Santosh Kumar Tiwari is Corresponding Author.

Funding: This work was financially supported by the Department of Biotechnology (DBT, BT/PR8911/NDB/39/423/2013) and Indian Council of Medical Research (ICMR, 5/9/1117/2013-NUT), New Delhi, India.

Conflicts of interest/Competing interests: The authors declare that they have no conflict of interest.

Availability of data and material: Not applicable.

Code availability: Not applicable.

\section{References}

1. Kim, Y., Jung, S., Ryu, H., Yoo, Y., Kim, S. M., \& Jeon, T. (2012). Synthetic biomimetic membranes and their sensor applications. Sensors (Basel, Switzerland), 12, 9530-9550. Doi:10.3390/s120709530.

2. Kolusheva, S., Lecht, S., Derazon, T., Jelinek, R., \& Lazarovici, P. (2008). Pardaxin a fish toxin peptide interaction with a biomimetic phospholipid/polydiacetylene membrane assay. Peptides, 29, 1620 1625. Doi:10.1016/j.peptides.2008.05.012. 
3. Yadav, M. K., Singh, B., \& Tiwari, S. K. (2019). Comparative analysis of inhibition-based and indicatorindependent colorimetric assay for screening of bacteriocin-producing lactic acid bacteria. Probiotics and Antimicrobial Proteins, 11, 687-695. Doi:10.1007/s12602-018-9445-4.

4. Thongmalai, W., Eaidkong, T., Ampornpun, S., Mungkarndee, R., Tumcharern, G., Sukwattanasinitta, M., \& Wacharasindhu, S. (2011). Polydiacetylenes carrying amino groups for colorimetric detection and identification of anionic surfactants. Journal of Materials Chemistry, 11, 16391-16397. Doi:10.1039/c1jm12795k.

5. Wegner, G. (1969). Topochemische, Reaktionen von Monomeren mit konjugierten Dreifachbindungen I. Mitt.: Polymerisation von Derivaten des 2.4-Hexadiin-1.6-diols im kristallinen Zustand. Z. Naturforsch. B. Journal of Chemical Science, 24B, 824-832. Doi:10.1515/znb-1969-0708.

6. Charych, D., Cheng, Q., Reichert, A., Kuziemko, G., Stroh, M., Nagyl, J. O., Pevakl, W., \& Stevens, R. C. (1996). A 'litmus test' for molecular recognition using artificial membranes. Chemistry \& Biology, 3 , 113-120. Doi:10.1016/S1074-5521(96)90287-2.

7. Cho, E., \& Jung, S. (2018). Biomolecule-Functionalized Smart Polydiacetylene for Biomedical and Environmental Sensing. Molecules, 23, 107. Doi:10.3390/molecules23010107.

8. Yarimaga, O., Jaworski, J., Yoon, B., \& Kim, J. (2012). Polydiacetylenes: supramolecular smart materials with a structural hierarchy for sensing, imaging and display applications. Chemical Communications, 48, 2469-2485. Doi:10.1039/c2cc17441c.

9. Ardila-Diaz, L. D., de Oliveira, T. V., \& Soares, N. d. F. F. (2020). Development and evaluation of the chromatic behavior of an intelligent packaging material based on cellulose acetate incorporated with polydiacetylene for an efficient packaging. Biosensors, 10, 59. Doi:10.3390/bios10060059.

10. Chen, X., Zhou, G., Peng, X., \& Yoon, J. (2012). Biosensors and chemosensors based on the optical responses of polydiacetylenes. Chemical Society Review, 41, 4610-4630. Doi:10.1039/c2cs35055f.

11. Wu, W., Zhang, J., Zheng, M., Zhong, Y., Yang, J., Zhao, Y., Wu, W., Ye, W., Wen, J., Wang, Q., \& Lu, J. (2012). An aptamer-based biosensor for colorimetric detection of Escherichia coli 0157:H7. PLoS ONE, 7, e48999. Doi:10.1371/journal.pone.0048999.

12. Zhang, W., Chen, Y., Shao, Y., \& Fan, J. (2014). Facile preparation of polydiacetylene-based uniform porous fluorescent microspheres for potential immunoassay applications. Journal of Materials Chemistry B, 2, 5249-5255. Doi:10.1039/c4tb00561a.

13. de Oliveira, C. P., Soares, N. d. F. F., Teixeira, A. V. N. d. C., de Oliveira, T. V., \& Filho, A. M. M. (2019). Biomimetic system characterization: $\mathrm{pH}$-induced chromatic transition and nanostructural transformation of polydiacetyle and dimyristoylphosphatidylcholine vesicles under $\mathrm{pH}$ variation using dynamic light scattering (DLS) technique. Journal of Food Chemistry \& Nanotechnology, 5 , 65-69. Doi: 10.17756/jfcn.2019-073.

14. Ortuso, R. D., Cataldi, U., \& Sugihara, K. (2017). Mechanosensitivity of polydiacetylene with a phosphocholine headgroup. Soft Matter, 13, 1728-1736. Doi:10.1039/c6sm02579j.

15. Xavier, J. R., Kumarr, M. M. M., Natarajan, G., Ramana, K. V., \& Semwal, A. D. (2019). Optimized production of poly ( $\mathrm{Y}$-glutamic acid) ( $\mathrm{Y}-\mathrm{PGA}$ ) using Bacillus licheniformis and its application as 
cryoprotectant for probiotics. Biotechnology and Applied Biochemistry, 00, 1-11. Doi:10.1002/bab.1879.

16. Ortuso, R. D., Ricardi, N., Burgi, T., Wesolowski, T. A., \& Sugihara, K. (2019). The deconvolution analysis of ATR-FTIR spectra of diacetylene during UV exposure. Spectrochimica Acta Part A: Molecular and Biomolecular Spectroscopy, 219, 23-32. Doi:10.1016/j.saa.2019.04.030.

17. Kolusheva, S., Shahal, T., \& Jelinek, R. (2000). Peptide-membrane interactions studied by a new phospholipid/polydiacetylene colorimetric vesicle assay. Biochemistry, 39, 15851-15859. Doi:10.1021/bi000570b.

18. Yadav, M. K., Kumar, V., Singh, B., \& Tiwari, S. K. (2017). Phospholipid/polydiacetylene vesicle-based colorimetric assay for high-throughput screening of bacteriocins and halocins. Applied Biochemistry and Biotechnology, 182, 142-154. Doi:10.1007/s12010-016-2316-0.

19. Sheynis, T., Sykora, J., Benda, A., Kolusheva, S., Hof, M., \& Jelinek, R. (2003). Bilayer localization of membrane-active peptides studied in biomimetic vesicles by visible and fluorescence spectroscopies. European Journal of Biochemistry, 270, 4478-4487. Doi:10.1046/j.1432-1033.2003.03840.

20. Lin, J., Motylinski, J., Krauson, A. J., Wimley, W. C., Searson, P. C., \& Hristova, K. (2012). Interactions of membrane active peptides with planar supported bilayers: an impedance spectroscopy study. Langmuir, 28, 6088-6096. Doi:10.1021/la300274n.

21. Mihajlovic, M., \& Lazaridis, T. (2010). Antimicrobial peptides bind more strongly to membrane pores. Biochimica et Biophysica Acta, 1798, 1494-1502. Doi:10.1016/j.bbamem.2010.02.023.

22. Meade, E., Slattery, M. A., \& Garvey, M. (2020). Bacteriocins, Potent antimicrobial peptides and the fight against multi drug resistant species: resistance is futile? Antibiotics, 9, 32. Doi: 10.3390/antibiotics9010032.

23. Sheoran, P., \& Tiwari, S. K. (2019). Enterocin LD3 from Enterococcus hirae LD3 causing efflux of intracellular ions and UV-absorbing materials in Gram-negative bacteria. Journal of Applied Microbiology, 126, 1059-1069. Doi:10.1111/jam.14203.

24. Gupta, A., \& Tiwari, S. K. (2014). Probiotic potential of Lactobacillus plantarum LD1 isolated from batter of Dosa, a South Indian fermented food. Probiotics and Antimicrobial Proteins, 6, 73-81. Doi:10.1007/s12602-014-9158-2.

25. Gupta, A., Tiwari, S. K., Netrebov, V., \& Chikindas, M. L. (2016). Biochemical properties and mechanism of action of enterocin LD3 purified from Enterococcus hirae LD3. Probiotics and Antimicrobial Proteins, 8, 161-169. Doi:10.1007/s12602-016-9217-y.

26. Kaur, R., \& Tiwari, S. K. (2018). Membrane-acting bacteriocin purified from a soil isolate Pediococcus pentosaceus LB44 shows broad host-range. Biochemical and Biophysical Research Communications, 498, 810-816. Doi:10.1016/j.bbrc.2018.03.062.

27. Kumar, V., \& Tiwari, S. K. (2017). Halocin HA1: An archaeocin produced by the haloarchaeon Haloferax larsenii HA1. Process Biochemistry, 61, 202-208. Doi:10.1016/j.procbio.2017.06.010.

28. Yuan, H., Zhang, W., Xiao, G., \& Zhan, J. (2020). Efficient production of gamma-aminobutyric acid by engineered Saccharomyces cerevisiae with glutamate decarboxylases from Streptomyces. 
Biotechnology and Applied Biochemistry, 67, 240-248. Doi:10.1002/bab.1840.

29. Kumariya, R., Sood, S. K., Rajput, Y. S., Saini, N., \& Garsa, A. K. (2015). Increased membrane surface positive charge and altered membrane fluidity leads to cationic antimicrobial peptide resistance in Enterococcus faecalis. Biochimica et Biophysica Acta, 1848, 1367-1375.

Doi:10.1016/j.bbamem.2015.03.007.

30. Kim, K. W., Lee, J. M., Kwon, Y. M., Choi, T., Kim, J. Y. H., Bae, S., \& Song, J. (2018). Polyaminefunctionalized polydiacetylene (PDA) vesicles for colorimetric sensing of carbon dioxide. Macromolecular Research, 26, 284-290. Doi:10.1007/s13233-018-6036-x.

31. de Oliveira, C. P., Soares, N. d. F. F., Fontes, E. A. F., de Oliveira, T. V., \& Filho, A. M. M. (2012). Behaviour of polydiacetylene vesicles under different conditions of temperature, $\mathrm{pH}$ and chemical components of milk. Food Chemistry, 135, 1052-1056. Doi:10.1016/j.foodchem.2012.05.076.

32. Kolusheva, S., Boyer, L., \& Jelinek, R. (2000). A colorimetric assay for rapid screening of antimicrobial peptides. Nature Biotechnology, 18, 225-227. Doi:10.1038/72697.

33. Boumehira, A. Z., Arous, O., Elsayed, E. A., Hacene, H., Yezli, N., Sukmawati, D., \& El-Enshasy, H. A. (2019). Application of attenuated total refelction/fourier transform infrared spectroscopy in the screening of strains producing bioactive molecules: A metabolomics approach. Journal of Scientific \& Industrial Research, 78, 301-306. Doi: nopr.niscair.res.in/handle/123456789/47153.

34. Zoumpopoulou, G., Pepelassi, E., Papaioannou, W., Georgalaki, M., Maragkoudakis, P. A., Tarantilis, P. A., Polissiou, M., Tsakalidou, E., \& Papadimitriou, K. (2013). Incidence of bacteriocins produced by food-related lactic acid bacteria active towards oral pathogens. International Journal of Molecular Sciences, 14, 4640-4654. Doi:10.3390/ijms14034640.

35. Ritenberg, M., Kolusheva, S., Ganin, H., Meijler, M. M., \& Jelinek, R. (2012). Biofilm formation on chromatic sol-gel/polydiacetylene films. ChemPlusChem, 77, 752-757.

Doi:10.1002/cplu.201200088.

36. Allen, H. K., Trachsel, J., Looft, T., \& Casey, T. A. (2013). Finding alternatives to antibiotics. Annals of The New York Academy of Sciences, 1323, 91-100. Doi:10.1111/nyas.12468.

37. Sand, S. L., Nissen-Meyer, J., Sand, O., \& Haug, T. M. (2013). Plantaricin A, a cationic peptide produced by Lactobacillus plantarum, permeabilizes eukaryotic cell membranes by a mechanism dependent on negative surface charge linked to glycosylated membrane proteins. Biochimica et Biophysica Acta, 1828, 249-259. Doi:10.1016/j.bbamem.2012.11.001.

38. Tiwari, S. K., Noll, K. S., Cavera, V. L., \& Chikindas, M. L. (2015). Improved Antimicrobial Activities of Synthetic-Hybrid Bacteriocins Designed from Enterocin E50-52 and Pediocin PA-1. Applied and Environmental Microbiology, 81, 1661-1667. Doi:10.1128/AEM.03477-14.

39. Sheoran, P., \& Tiwari, S. K. (2019). Anti-staphylococcal activity of bacteriocins of food isolates Enterococcus hirae LD3 and Lactobacillus plantarum LD4 in pasteurized milk. 3 Biotech, 9, 8. Doi:10.1007/s13205-018-1546-y.

40. Reddy Tadi, S. R., Limaye, E. V. R. A., A. M., \& Sivaprakasam, S. (2017). Enhanced production of optically pure d (-) lactic acid from nutritionally rich Borassus flabellifer sugar and whey protein 
hydrolysate based-fermentation medium. Biotechnology and Applied Biochemistry, 64, 279-289. Doi:10.1002/bab.1470.

41. Qian, X., \& Stadler, B. (2020). Polydiacetylene-based biosensors for the detection of viruses and related biomolecules. Advance Functional Materials, 30, 2004605-2004617. Doi:10.1002/adfm.202004605.

42. Gupta, A., \& Tiwari, S. K. (2014). Plantaricin LD1: a bacteriocin produced by food isolate of Lactobacillus plantarum LD1. Applied Biochemistry and Biotechnology, 172, 3354-3362. Doi:10.1007/s12010-014-0775-8.

43. Zhou, C., You, T., Jang, H., Ryu, H., Lee, E. S., Oh, M. H., Huh, Y. S., Kim, S. M., \& Jeon, T. J. (2020). Aptamer-conjugated polydiacetylene colorimetric paper chip for the detection of Bacillus thuringiensis spores. Sensors (Basel, Switzerland), 20, 3124. Doi:10.3390/s20113124.

44. Beasley, M., Stonebraker, A. R., \& Legleiter, J. (2020). Normalizing polydiacetylene colorimetric assays of vesicle binding across lipid systems. Analytical Biochemistry, 609, 113864.

Doi:10.1016/j.ab.2020.113864.

45. Adhikary, R. R., Koppak, O., \& Banerjee, R. (2020). Development of color changing polydiacetylenebased biomimetic nanovesicle platforms for quick detection of membrane permeability across the blood brain barrier. Nanoscale, 12, 8898-8908. Doi:10.1039/C9NR07845B.

46. Gomes, P. J., da Silva, A. M. P. S. G., Ribeiro, P. A., Oliveira, O. N. Jr., \& Raposo, M. (2016). Radiation damage on Langmuir monolayers of the anionic 1.2-dipalmitoyl-sn-glycero-3-[phospho-rac-(1glycerol)] (sodium salt) (DPPG) phospholipid at the air-DNA solution interface. Materials Science and Engineering: C, 58, 576-579. Doi:10.1016/j.msec.2015.09.017.

47. Morales, M. C. S., Juarez, A. C., Montich, G. G., \& Alvarez, R. M. S. (2019). Interaction of the antibiotic peptide nisin with anionic membranes in different phase-states: a vibrational study. Spectrochimica Acta Part A Molecular and Biomolecular Spectroscopy, 215, 389-397.

Doi:10.1016/J.SAA.2019.03.009.

48. Kolusheva, S., Friedman, J., Angel, I., \& Jelinek, R. (2005). Membrane interactions and metal ion effects on bilayer permeation of the lipophilic ion modulator DP-109. Biochemistry, 44, 1207712085. Doi:10.1021/bi050718x.

\section{Figures}



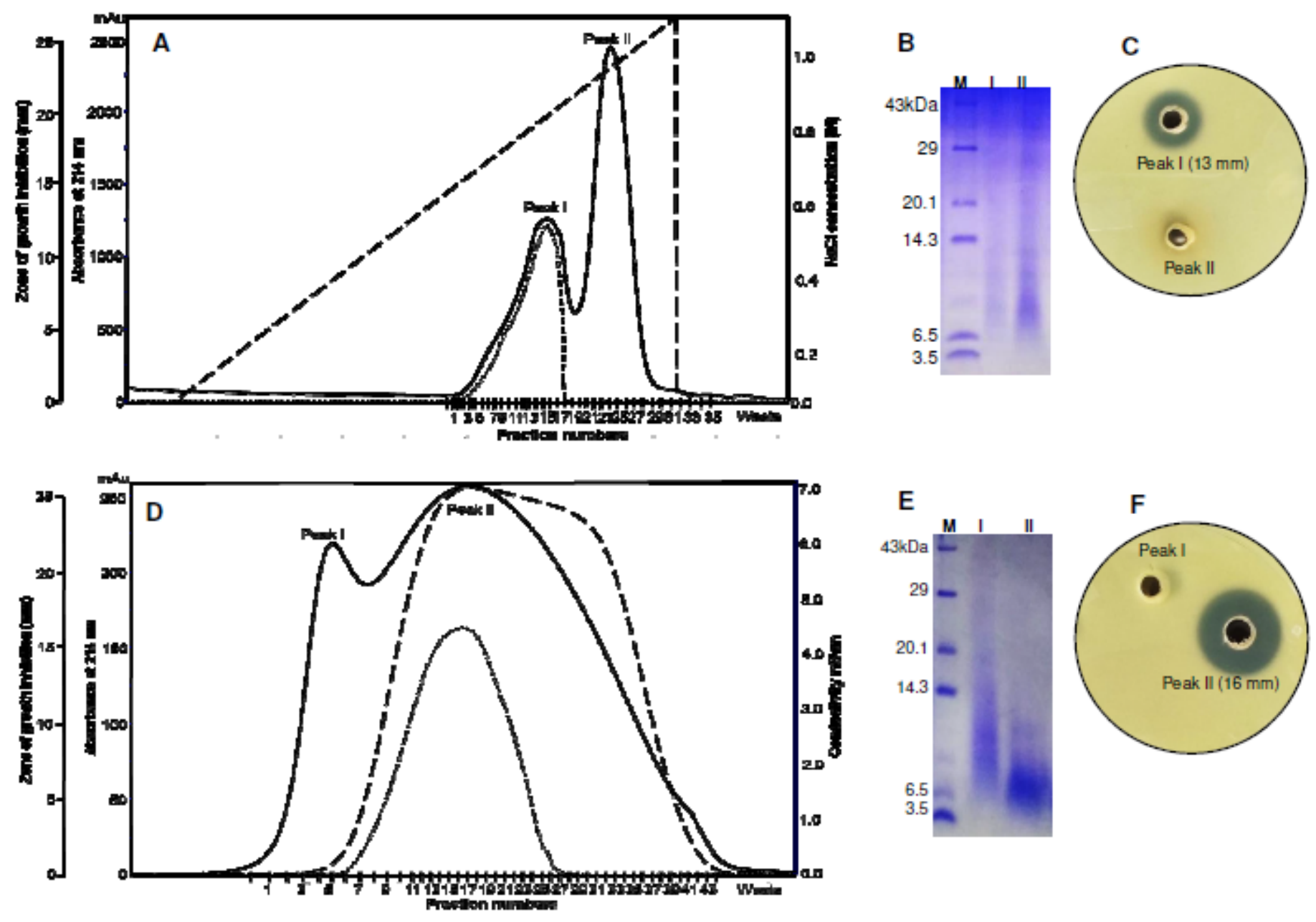

Figure 1

Purification of plantaricin LD1 using cation-exchange chromatography $(A)$, the solid line represents protein absorbance, the dash line represents concentration of $\mathrm{NaCl}(\mathrm{M})$ and dotted line represents antimicrobial activity. Tricine SDS-PAGE (B) of eluted fraction no. 1 to 20 (peak I, lane II) and fraction no. 21 to 40 (peak II, lane I). The antimicrobial activity of peak I and II against Micrococcus luteus MTCC106 (C). Gel-filtration chromatography of CEC-eluted fractions (D), the solid line represents protein absorbance, the dash line represents conductivity $(\mathrm{mS} / \mathrm{cm})$ and dotted line represents antimicrobial activity. Tricine SDS-PAGE of pooled GFC fraction no. 1 to 5 (peak I, lane I) and fraction no. 6 to 25 (peak II, lane II) showed protein band near $6.5 \mathrm{kDa}(\mathrm{E})$. Antimicrobial activity of peak I and II of gel eluted fraction (F). 

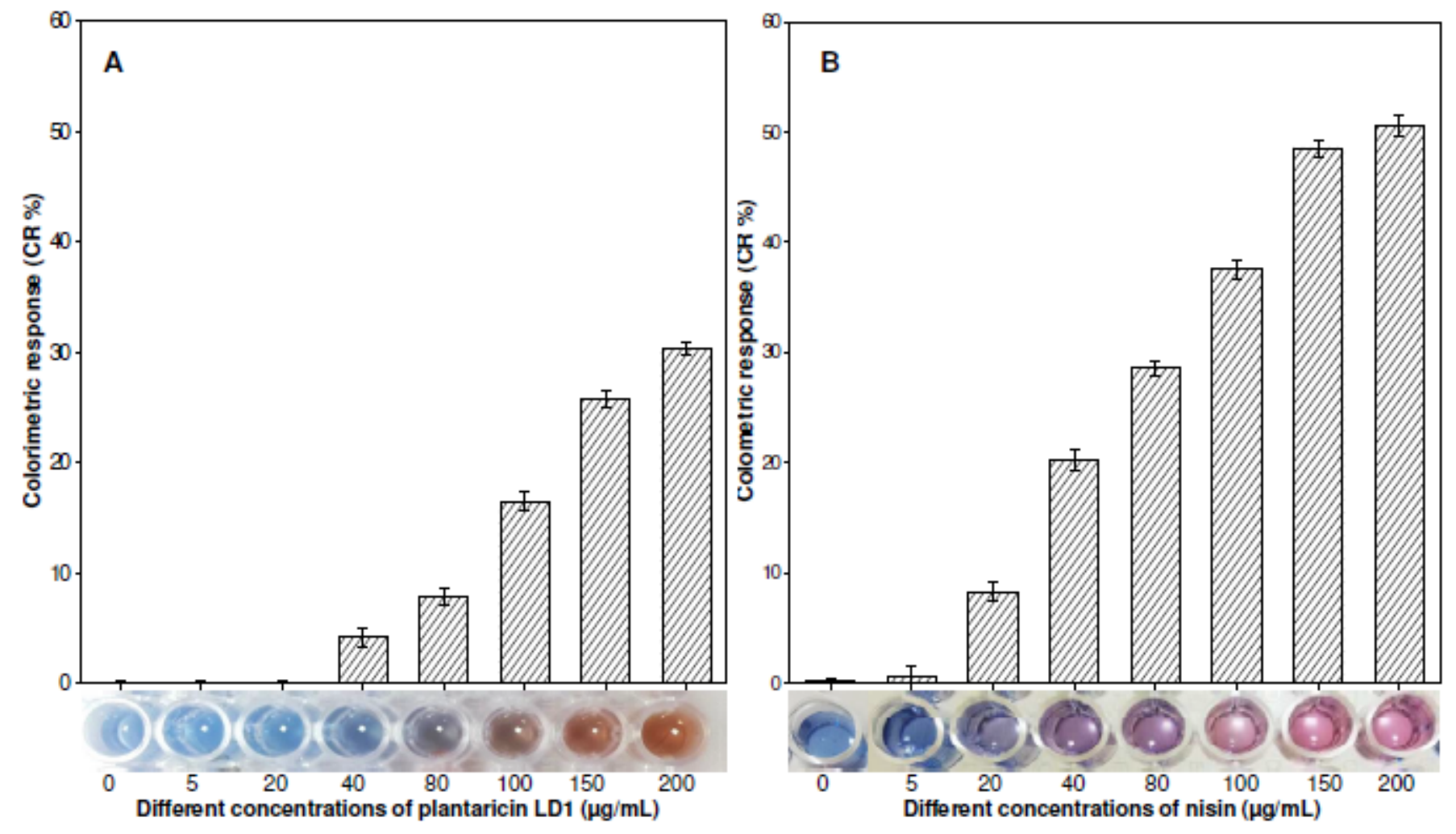

Figure 2

Colorimetric response (CR \%) of PDA vesicles treated with different concentrations of plantaricin LD1 (A) and nisin (B). The untreated PDA vesicles (without bacteriocin treatment) was used as control and shown in blue color. The treated vesicles showed purple to pink color in the presence of different concentrations of bacteriocins. 


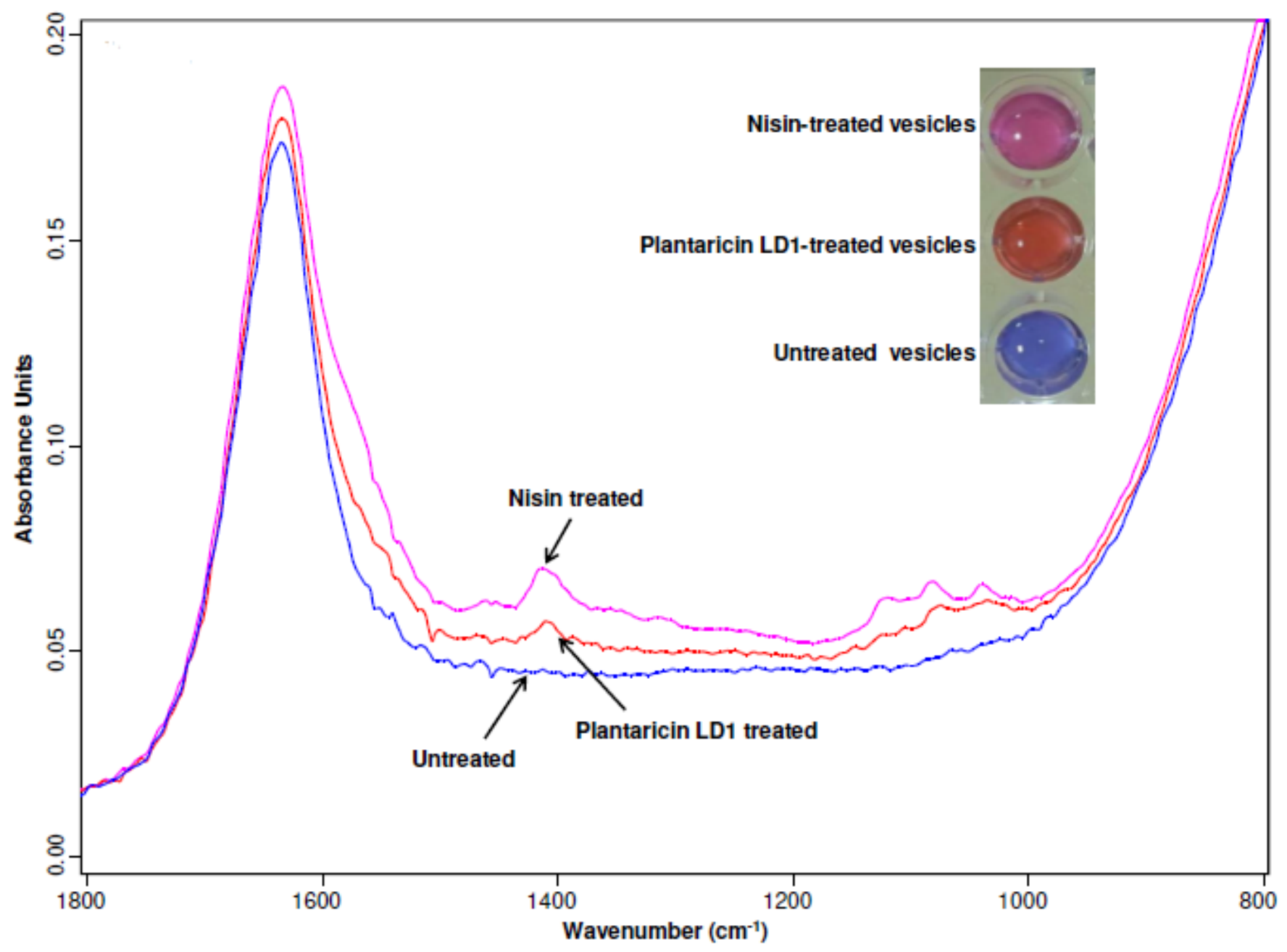

Figure 3

Fourier transform infrared (FTIR) absorbance spectra of PDA vesicles with nisin (pink line)) and plantaricin LD1 (red line) showed increase in absorbance at 1411.46 and $1000-1150 \mathrm{~cm}-1$. The untreated vesicles did not change the spectra. The color change of treated and untreated PDA vesicles has been shown in inset. 

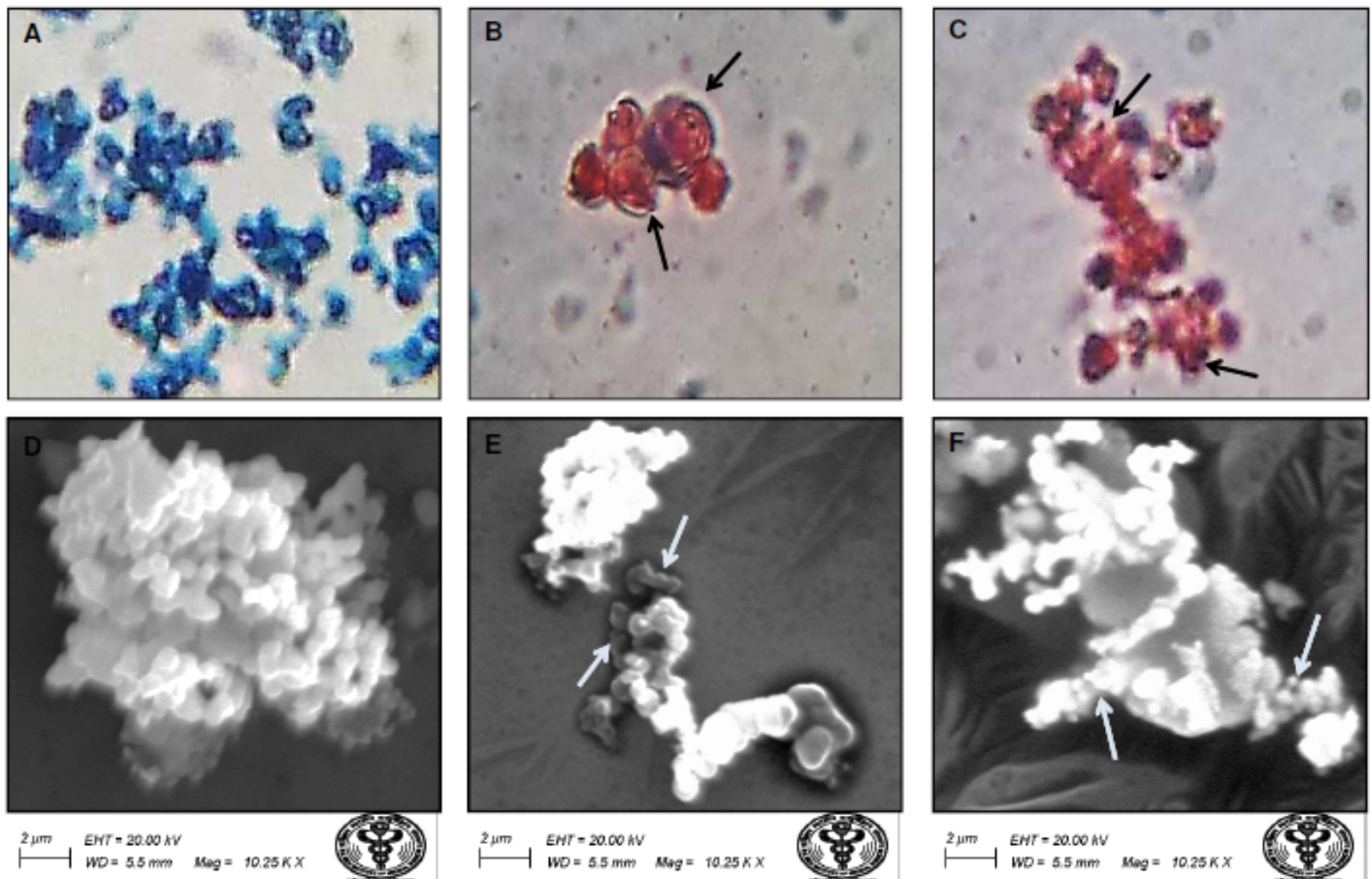

$2 \mu \mathrm{mm}, E M T=20.00 \mathrm{hV}$

$\longmapsto$ WD $=5.5 \mathrm{~mm} \quad \mathrm{Mag}=10.25 \mathrm{KX}$

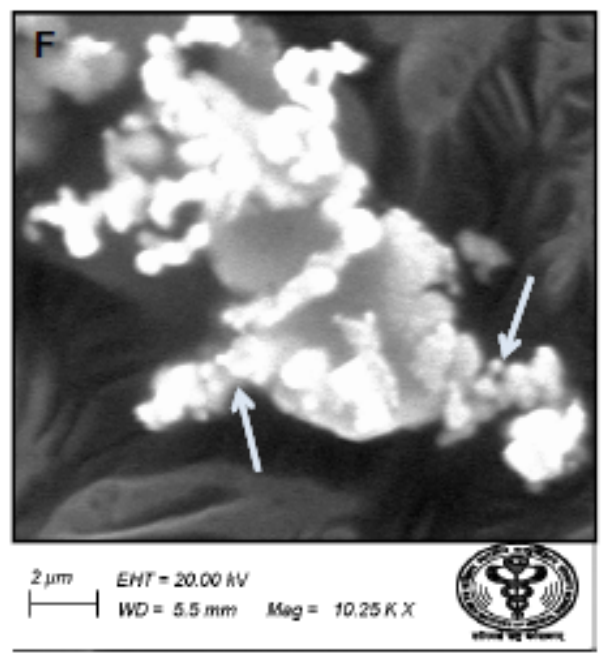

Figure 4

Light microscopic $(100 \mathrm{x}$ ) images of untreated PDA vesicles showed blue color with entire boundary (A) whereas PDA vesicles treated with plantaricin LD1 (B) and nisin (C) showed pink color with rough boundary. Under scanning electron microscopy $(10.25 \mathrm{Kx})$, untreated vesicles were found to be normal, whereas, plantaricin LD1-treated (D) and nisin-treated vesicles were larger in size with broken outer boundary (E-F). The arrow indicates broken and swollen vesicles after treatment with bacteriocins. 